\title{
MCL1 Gene
}

National Cancer Institute

\section{Source}

National Cancer Institute. MCL1 Gene. NCI Thesaurus. Code C20412.

This gene is a regulator of apoptosis and plays a role in differentiation. 